\title{
EDEMA PARU KARDIOGENIK AKUT
}

\author{
Starry H. Rampengan \\ Bagian Ilmu Penyakit Jantung dan Pembuluh Darah \\ Fakultas Kedokteran Universitas Sam Ratulangi Manado \\ Email: starry8888@yahoo.com
}

\begin{abstract}
Acute cardiogenic pulmonary edema is a common disease, harmful and lethal with a mortality rate $10-20 \%$. Cardiogenic pulmonary edema or edema volume overload due to an increase of pulmonary capillary hydrostatic pressure that causes the increase of transvascular fluid filtration. The increase of pulmonary capillary hydrostatic pressure is usually caused by the increase of pressure in the pulmonary veins that occur due to the increase of left ventricular end-diastolic pressure and left atrial pressure. Clinical features of cardiogenic pulmonary edema are inter alia shortness of breath that is associated with a history of chest pain and heart disease. Cardiogenic pulmonary edema is one of medical emergencies that need early medical treatment after the diagnosis is established. The management includes supportive treatment to maintain lung function (such as gas exchange, organ perfusion), where as the main cause should be investigated and treated as soon as possible whenever possible. The principle of management are adequate oxygen distribution, fluid restriction, and maintain cardiovascular function. The initial consideration are clinical evaluation, ECG, chest x-ray and blood gas analysis.
\end{abstract}

Keywords: acute cardiogenic pulmonary edema, management

\begin{abstract}
Abstrak: Edema paru kardiogenik akut merupakan penyakit yang sering terjadi, merugikan dan mematikan dengan tingkat kematian 10-20\%. Edema paru kardiogenik atau edema volume overload terjadi karena peningkatan tekanan hidrostatik dalam kapiler paru yang menyebabkan peningkatan filtrasi cairan transvaskular. Peningkatan tekanan hidrostatik kapiler paru biasanya disebabkan oleh meningkatnya tekanan di vena pulmonalis yang terjadi akibat meningkatnya tekanan akhir diastolik ventrikel kiri dan tekanan atrium kiri. Gambaran klinis edema paru kardiogenik yaitu adanya sesak napas tiba-tiba yang dihubungkan dengan riwayat nyeri dada dan adanya riwayat sakit jantung. Edema paru kardiogenik merupakan salah satu kegawatan medis yang perlu penanganan medis secepat mungkin setelah ditegakkan diagnosis. Penatalaksanaan utama meliputi pengobatan suportif yang ditujukan terutama untuk mempertahankan fungsi paru (seperti pertukaran gas, perfusi organ), sedangkan penyebab utama juga harus diselidiki dan diobati segera bila memungkinkan. Prinsip penatalaksanaan meliputi pemberian oksigen yang adekuat, restriksi cairan, mempertahankan fungsi kardiovaskular. Pertimbangan awal yaitu evaluasi klinis, EKG, foto toraks dan AGDA.
\end{abstract}

Kata kunci: edema paru kardiogenik akut, tatalaksana

Edema paru didefinisikan sebagai suatu keadaan dimana terjadi perpindahan cairan dari vaskular paru ke interstisial dan alveoli paru. ${ }^{1}$ Pada edema paru terdapat penimbunan cairan serosa atau serosanguinosa secara berlebihan di dalam ruang interstisial dan alveoli paru. Edema yang terjadi akut dan luas sering disusul oleh kematian dalam waktu singkat. $^{2}$

Edema paru dapat diklasifikasikan sebagai edema paru kardiogenik dan edema paru non-kardiogenik. Edema paru kardio- 
genik disebabkan oleh peningkatan tekanan hidrostatik kapiler paru yang dapat terjadi akibat perfusi berlebihan baik dari infus darah maupun produk darah dan cairan lainnya, sedangkan edema paru nonkardiogenik disebabkan oleh peningkatan permeabilitas kapiler paru antara lain pada pasca transplantasi paru dan reekspansi edema paru, termasuk cedera iskemiareperfusi-dimediasi. ${ }^{1,3-5}$ Walaupun penyebab edema paru kardiogenik dan nonkardiogenik berbeda, namun keduanya memiliki penampilan klinis yang serupa sehingga menyulitkan dalam menegakkan diagnosisnya. ${ }^{6}$ Terapi yang tepat dibutuhkan untuk menyelamatkan pasien dari kerusakan lanjut akibat gangguan keseimbangan cairan di paru. ${ }^{1,3,4,7}$

Menurut penelitian pada tahun 1994, secara keseluruhan terdapat 74,4 juta penderita edema paru di seluruh dunia. Di Inggris terdapat sekitar 2,1 juta penderita edema paru yang memerlukan pengobatan dan pengawasan secara komprehensif. Di Amerika Serikat diperkirakan 5,5 juta penduduk menderita edema paru. Di Jerman penderita edema paru sebanyak 6 juta penduduk. Ini merupakan angka yang cukup besar yang perlu mendapat perhatian dari medik di dalam merawat penderita edema paru secara komprehensif.

Di Indonesia, edema paru pertama kali terdeteksi pada tahun 1971. Sejak itu penyakit tersebut dilaporkan di berbagai daerah sehingga sampai tahun 1980 sudah mencakup seluruh propinsi di Indonesia. Sejak pertama kali ditemukan, jumlah kasus menunjukkan kecenderungan meningkat baik dalam jumlah maupun luas wilayah. Di Indonesia insiden tersebar terjadi pada 1998 dengan incidence rate $(\mathrm{IR})=35,19$ per 100.000 penduduk dan $\mathrm{CFR}=2 \%$. Pada tahun $1999 \mathrm{IR}$ menurun tajam sebesar $10,17 \%$, namun pada tahuntahun berikutnya IR cenderung meningkat yaitu 15,99 \% (tahun 2000), 19,24\% (tahun 2002), dan 23,87\% (tahun 2003). ${ }^{2,8}$ Edema paru kardiogenik akut (Acute cardiogenic pulmonary edema/ACPE) sering terjadi, dan berdampak merugikan dan mematikan dengan tingkat kematian 10$20 \%{ }^{9}$

\section{PATOFISIOLOGI}

Dalam keadaan normal di dalam paru terjadi aliran yang kontinyu dari cairan dan protein intravaskular ke jaringan interstisial dan kembali ke sistem aliran darah melalui saluran limf yangn memenuhi hukum Starling $\mathrm{Q}=\mathrm{K}(\mathrm{Pc}-\mathrm{Pt})-\mathrm{d}(\mathrm{c}-\mathrm{t}) .^{4,5,7}$

Edema paru terjadi bila cairan yang difiltrasi oleh dinding mikrovaskuler lebih banyak daripada yang bisa dikeluarkan yang berakibat alveoli penuh terisi cairan sehingga tidak memungkinkan terjadinya pertukaran gas. $^{4-7}$ Faktor-faktor penentu yang berperan disini yaitu perbedaan tekanan hidrostatik dan onkotik dalam lumen kapiler dan interstisial, serta permeabilitas sel endotel terhadap air, larutan, dan molekul besar seperti protein plasma. Adanya ketidakseimbangan dari satu atau lebih dari faktor-faktor diatas akan menimbulkan terjadinya edema paru. ${ }^{7}$

Pada edema paru kardiogenik (volume overload edema) terjadinya peningkatan tekanan hidrostatik dalam kapiler paru menyebabkan peningkatan filtrasi cairan transvaskular. Bila tekanan interstisial paru lebih besar daripada tekanan intrapleural maka cairan bergerak menuju pleura viseral yang menyebabkan efusi pleura. Bila permeabilitas kapiler endotel tetap normal, maka cairan edema yang meninggalkan sirkulasi memiliki kandungan protein rendah. Peningkatan tekanan hidrostatik kapiler paru biasanya disebabkan oleh meningkatnya tekanan di vena pulmonalis yang terjadi akibat meningkatnya tekanan akhir diastolik ventrikel kiri dan tekanan atrium kiri $(>25 \mathrm{mmHg})$. Dalam keadaan normal tekanan kapiler paru berkisar 8-12 mmHg dan tekanan osmotik koloid plasma $28 \mathrm{mmHg}{ }^{1,3,7,10,11}$ Kejadian tersebut akan menimbulkan lingkaran setan yang terus memburuk oleh proses-proses sebagai berikut:

1. Meningkatnya kongesti paru menyebabkan desaturasi dan menurunnya 
pasokan oksigen miokard memperburuk fungsi jantung.

2. Hipoksemia dan meningkatnya cairan di paru menimbulkan vasokonstriksi pulmonal sehingga meningkatkan tekanan ventrikel kanan yang melalui mekanisme interdependensi ventrikel akan semakin menurunkan fungsi ventrikel kiri.

3. Insufisiensi sirkulasi menyebabkan asidosis sehingga memperburuk fungsi jantung.

Keluarnya cairan edema dari alveoli paru tergantung pada transpor aktif ion $\mathrm{Na}^{+}$ dan $\mathrm{Cl}^{-}$melintasi barier epitel yang terdapat pada membran apikal sel epitel alveolar tipe I dan II serta epitel saluran napas distal. Ion $\mathrm{Na}^{+}$secara aktif ditranspor keluar ke ruang insterstisial oleh kerja $\mathrm{Na} / \mathrm{K}$-ATPase yang terletak pada membran basolateral sel tipe II. Air secara pasif mengikuti, kemungkinan melalui aquaporins yang merupakan saluran air pada sel tipe $\mathrm{I}^{10^{\circ}}$

Edema paru kardiogenik dapat terjadi akibat dekompensasi akut pada gagal jantung kronik maupun akibat gagal jantung akut pada infark miokard dimana terjadinya bendungan dan peningkatan tekanan di jantung dan paru akibat melemahnya pompa jantung. ${ }^{11}$ Kenaikan tekanan hidrostatik kapiler paru menyebabkan transudasi cairan ke dalam ruang interstisial paru, dimana tekanan hidrostatik kapiler paru lebih tinggi dari tekanan osmotik koloid plasma. Pada tingkat kritis, ketika ruang interstitial dan perivaskular sudah terisi, maka peningkatan tekanan hidrostatik menyebabkan penetrasi cairan ke dalam ruang alveoli.

Terdapat tiga tingkatan fisiologi dari akumulasi cairan pada edema paru kardiogenik: ${ }^{7,12}$

Tingkat 1: Cairan dan koloid berpindah dari kapiler paru ke interstisial paru tetapi terdapat peningkatan cairan yang keluar dari aliran limfatik.

Tingkat 2: Kemampuan pompa sistem limfatik telah terlampaui sehingga cairan dan koloid mulai terakumulasi pada ruang interstisial sekitar bronkioli, arteriol, dan venula.

Tingkat 3: Peningkatan akumulasi cairan menyebabkan terjadinya edema alveoli. Pada tahap ini mulai terjadi gangguan pertukaran gas.

\section{ETIOLOGI}

Edema paru biasanya diakibatkan oleh peningkatan tekanan pembuluh kapiler paru dan permeabilitas kapiler alveolar. Edema paru akibat peningkatan permeabilitas kapiler paru sering disebut acute respiratory distress syndrome (ARDS). ${ }^{8}$

Pada keadaan normal terdapat keseimbangan tekanan onkotik (osmotik) dan hidrostatik antara kapiler paru dan alveoli. Tekanan hidrostatik yang meningkat pada gagal jantung menyebabkan edema paru, sedangkan pada gagal ginjal terjadi retensi cairan yang menyebabkan volume overload dan diikuti edema paru. Hipoalbuminemia pada sindrom nefrotik atau malnutrisi menyebabkan tekanan onkotik menurun sehingga terjadi edema paru. Pada tahap awal edema paru terdapat peningkatan kandungan cairan di jaringan interstisial antara kapiler dan alveoli. Pada edema paru akibat peningkatan permeabilitas kapiler paru perlu dipikirkan bahwa kaskade inflamasi timbul beberapa jam kemudian yang berasal dari suatu fokus kerusakan jaringan tubuh. Neutrofil yang teraktivasi akan beragregasi dan melekat pada sel endotel yang kemudian menyebabkan pelepasan berbagai toksin, radikal bebas, dan mediator inflamasi seperti asam arakidonat, kinin, dan histamin. Proses kompleks ini dapat diinisiasi oleh berbagai macam keadaan atau penyakit dengan hasil akhir kerusakan endotel yang berakibat peningkatan permeabilitas kapiler alveolar. Alveoli menjadi terisi penuh dengan eksudat yang kaya protein dan banyak mengandung neutrofil dan sel-sel inflamasi sehingga terbentuk membran hialin. Karakteristik edema paru akibat 
peningkatan permeabilitas kapiler paru ialah tidak adanya peningkatan tekanan pulmonal (hipertensi pulmonal). ${ }^{8}$ ialah: ${ }^{13}$

Penyebab edema paru kardiogenik

1. Gagal jantung kiri, yang dapat diakibatkan oleh: infark miokard, penyakit katup aorta dan mitral, kardiomiopati, aritmia, hipertensi krisis, kelainan jantung bawaan (paten duktus arteriosus, ventrikel septal defek)

2. Volume overload

3. Obstruksi mekanik aliran kiri

4. Insufisiensi limfatik, yang terjadi sebagai akibat lanjut transplantasi paru, karsinomatosis limfangiektasis, atau limfangitis fibrosis

\section{DIAGNOSIS}

Manifestasi klinis edema paru baik kardiogenik maupun non-kardiogenik bisa serupa; oleh sebab itu sangat penting untuk menetapkan gejala yang dominan dari kedua jenis tersebut sebagai pedoman pengobatan. ${ }^{1}$ Tabel 1 memperlihatkan perbedaan edema paru kardiogenik dan non-kardiogenik berdasarkan anamnesis, pemeriksaan fisik, dan pemeriksaan penunjang. ${ }^{14}$

Tabel 1. Perbedaan edema paru kardiogenik dan non-kardiogenik ${ }^{14}$

\begin{tabular}{|c|c|c|}
\hline Pemeriksaan & Kardiogenik & Non-kardiogenik \\
\hline Anamnesis & Kejadian kardiovaskular (+) & $\begin{array}{l}\text { Penyakit } \\
\text { mendasari (+) }\end{array}$ \\
\hline \multicolumn{3}{|l|}{ Pemeriksaan fisik } \\
\hline - Akral & Dingin & Hangat, nadi kuat \\
\hline - Tekanan vena jugular & Meningkat & Tak meningkat \\
\hline - Ronki & Basah & Kering \\
\hline \multicolumn{3}{|l|}{ Penunjang } \\
\hline - $\mathrm{EKG}$ & Iskemia/infark & Biasanya normal \\
\hline - Foto toraks & Distribusi perihiler & Distribusi perifer \\
\hline - Enzim kardiak & Dapat meningkat & Biasanya normal \\
\hline - PCWP) & $>18 \mathrm{mmHg}$ & $<18 \mathrm{mmHg}$ \\
\hline - Rasio $\mathrm{PaO}_{2} / \mathrm{FiO}_{2}$ & $\begin{array}{l}\text { Normal atau } \\
\text { sedikit menurun }\end{array}$ & $\leq 300$ \\
\hline - Hipoksemia & $(+)$ & Berat \\
\hline - Rasio protein edema dan plasma & $<0,5$ & $>0,7$ \\
\hline
\end{tabular}

\section{GAMBARAN KLINIS}

Gambaran klinis edema paru yaitu dari anamnesis ditemukan adanya sesak napas yang bersifat tiba-tiba yang dihubungkan dengan riwayat nyeri dada dan riwayat sakit jantung. Perkembangan edema paru bisa berangsur-angsur atau tiba-tiba seperti pada kasus edema paru akut. Selain itu, sputum dalam jumlah banyak, berbusa dan berwarna merah jambu. Gejala-gejala umum lain yang mungkin ditemukan ialah: mudah lelah, lebih cepat merasa sesak napas dengan aktivitas yang biasa (dyspnea on exertion), napas cepat (takipnea), pening, atau kelemahan. Tingkat oksigenasi darah yang rendah (hipoksia) mungkin terdeteksi pada pasien dengan edema paru. Pada auskultasi dapat didengar suara-suara paru yang abnormal, seperti ronki atau crakles. $1,3,8$

Pemeriksaan penunjang yang dilakukan untuk menegakkan diagnosis, yaitu:

1. Pemeriksaan foto toraks menunjukkan kardiomegali (pada pasien dengan CHF) dan adanya edema alveolar disertai efusi pleura dan infiltrasi bilateral dengan 
pola butterfly, gambaran vaskular paru dan hilus yang berkabut serta adanya garis-garis Kerley b di interlobularis. Gambaran lain yang berhubungan dengan penyakit jantung berupa pembesaran ventrikel kiri sering dijumpai. Efusi pleura unilateral juga sering dijumpai dan berhubungan dengan gagal jantung kiri. ${ }^{1,3}$

2. EKG menunjukan gangguan pada jantung seperti pembesaran atrium kiri, pembesaran ventrikel kiri, aritmia, miokard iskemik maupun infark. ${ }^{3}$

3. Ekokardiografi dilakukan untuk mengetahui apakah ada penurunan fungsi dari ventrikel kiri dan adanya kelainan katup-katup jantung. ${ }^{3,13}$

4. Pemeriksaan laboratorium enzim jantung perlu dilakukan untuk membantu menegakkan diagnosis infark miokard. Peningkatan kadar brain natriuretic peptide (BNP) di dalam darah sebagai respon terhadap peningkatan tekanan di ventikel; kadar $\mathrm{BNP}>500 \mathrm{pg} / \mathrm{ml}$ dapat membantu menegakkan diagnosis edema paru kardiogenik. $^{13,15,16}$

5. Analisis gas darah (AGDA) dapat memperlihatkan penurunan $\mathrm{PO}_{2}$ dan $\mathrm{PCO}_{2}$ pada keadaan awal tetapi pada perkembangan penyakit selanjutnya $\mathrm{PO}_{2}$ semakin menurun sedangkan $\mathrm{PCO}_{2}$ meningkat. Pada kasus yang berat biasanya dijumpai hiperkapnia dan asidosis respiratorik. ${ }^{1,3,13}$

6. Kateterisasi jantung kanan: Pengukuran $\mathrm{P}{ }^{\mathrm{pw}}$ (pulmonary capillary wedge pressure) melalui kateterisasi jantung kanan merupakan baku emas untuk pasien edema paru kardiogenik yaitu berkisar 25-35 mmHg sedangkan pada pasien ARDS $\mathrm{P}^{\mathrm{pw}}$ 0-18 mmHg.

7. Kadar protein cairan edema: Pengukuran rasio konsentrasi protein cairan edema dibandingkan protein plasma dapat digunakan untuk membedakan edema paru kardiogenik dan non-kardiogenik. Bahan pemeriksaan diambil dengan pengisapan cairan edema paru melalui pipa endotrakeal atau bronkoskop dan pengambilan plasma. Pada edema paru kardiogenik, konsentrasi protein cairan edema relatif rendah dibanding plasma (rasio <0,6). Pada edema paru nonkardiogenik konsentrasi protein cairan edema relatif lebih tinggi (rasio $>0,7$ ) karena sawar mikrovaskular berkurang. ${ }^{14}$

\section{PENATALAKSANAAN}

Edema paru kardiogenik merupakan salah satu kegawatan medis yang perlu penanganan secepat mungkin setelah ditegakkan diagnosis. ${ }^{3}$ Penatalaksanaan utama meliputi pengobatan suportif yang ditujukan terutama untuk mempertahankan fungsi paru (seperti pertukaran gas, perfusi organ), sedangkan penyebab utama juga harus diselidiki dan diobati sesegera mungkin bila memungkinkan. ${ }^{1,13}$

Prinsip penatalaksanaan meliputi pemberian oksigen yang adekuat, restriksi cairan, dan mempertahankan fungsi kardiovaskular. ${ }^{1,13}$ Pertimbangan awal ialah dengan evaluasi klinis, EKG, foto toraks, dan AGDA (Gambar 1). ${ }^{1}$

\section{Suplementasi oksigen}

Hipoksemia umum pada edema paru merupakan ancaman utama bagi susunan saraf pusat, baik berupa turunnya kesadaran sampai koma maupun terjadinya syok. Oleh karena itu suplementasi oksigen merupakan terapi intervensi yang penting untuk meningkatkan pertukaran gas dan menurunkan kerja pernapasan, mengoptimalisasi unit fungsional paru sebanyak mungkin, serta mengurangi overdistensi alveolar. $^{13}$

Pada kasus ringan oksigen bisa diberikan dengan kanul hidung atau masker muka (face mask). Continuous positive airway pressure (CPAP) sangat membantu pada pasien edema paru kardiogenik. ${ }^{1,13}$ Masip et al. mendapatkan bahwa penggunaan CPAP menurunkan kebutuhan akan intubasi dan angka mortalitas. ${ }^{17}$

Pada pasien dengan edema paru kardiogenik akut, induksi ventilasi noninvasif dalam gangguan pernapasan dan 


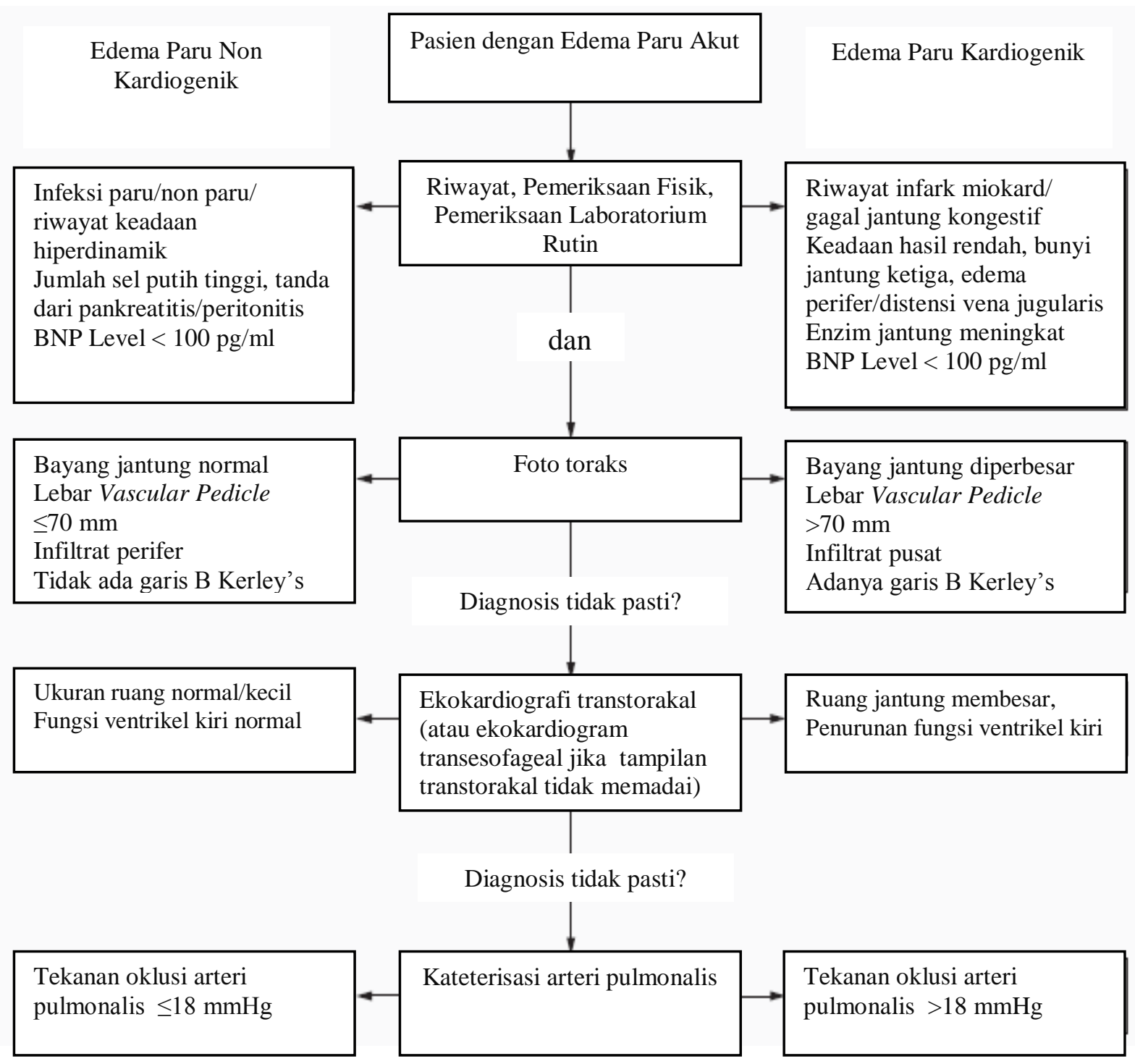

Gambar 1. Algoritme langkah-langkah untuk membedakan antara edema paru kardiogenik dan non-kardiogenik. Sumber: Ware LB dan Matthay MA, $2005 .{ }^{3}$

gangguan metabolik meningkat lebih cepat daripada terapi oksigen standar tetapi tidak berpengaruh terhadap mortalitas jangka pendek. ${ }^{18}$ Ventilasi non-invasif dengan CPAP telah terbukti menurunkan intubasi endotrakeal dan kematian pada pasien dengan edema paru akut kardiogenik. ${ }^{19}$ Menurut penelitian Agarwal et al., noninvasive pressure support ventilation (NIPSV) tampaknya aman dan berkhasiat sebagai CPAP, daripada jika bekerja dengan titrasi pada tekanan tetap. ${ }^{19}$

Penelitian Winck et al. mendukung penggunaan CPAP dan non-invasive positive pressure ventilation (NPPV) pada edema paru akut kardiogenik. Kedua teknik tersebut dipakai untuk menurunkan need for endotracheal intubation (NETI) dan kematian dibandingkan standard medical therapy (SMT), serta tidak menunjukkan peningkatan risiko infark miokard akut. CPAP dianggap sebagai intervensi pertama dari NPPV yang tidak menunjukkan khasiat yang lebih baik bahkan pada pasien dengan kondisi lebih parah, tetapi lebih murah dan lebih mudah untuk diimplementasikan dalam praktek klinis. ${ }^{20}$ Intubasi dan penggunaan ventilasi mekanik dengan positive end-expiratory pressure (PEEP) diperlukan pada kasus yang berat. ${ }^{11,13}$ 


\section{Obat-obatan}

\section{Obat-obatan yang menurunkan preload}

Nitrogliserin (NTG) dapat menurunkan preload secara efektif, cepat, dan efeknya dapat diprediksi. Pemberian NTG secara intra vena diawali dengan dosis rendah $(20 \mu \mathrm{g} / \mathrm{menit})$ dan kemudian dinaikkan secara bertahap (dosis maksimal $200 \mu \mathrm{g} /$ menit). ${ }^{1,13}$

Loop diuretics (furosemide) dapat menurunkan preload melalui 2 mekanisme, yaitu: diuresis dan venodilatasi. Dosis furosemide dapat diberikan per oral 20-40 $\mathrm{mg} /$ hari pada keadaan yang ringan hingga 5-40 mg/jam secara infus pada keadaan yang berat. ${ }^{1,13}$

Morfin sulfat digunakan untuk menurunkan preload dengan dosis $3 \mathrm{mg}$ secara intra vena dan dapat diberikan berulang. ${ }^{1,13}$

\section{Obat-obatan yang menurunkan afterload}

Angiotensin-converting enzyme inhibitors (ACE inhibitors) menunurunkan after load, serta memperbaiki volume sekuncup dan curah jantung. Pemberian secara intra vena (enalapril 1,25 mg) ataupun sublingual (captopril $25 \mathrm{mg}$ ) akan memperbaiki keluhan pasien. Pada suatu meta analisis didapati bahwa pemberian ACE inhibitors akan menurunkan angka mortalitas. ${ }^{1,13}$

\section{Obat-obatan golongan inotropik}

Obat-obatan golongan inotropik diberikan pada edema paru kardiogenik yang mengalami hipotensi, yaitu dobutamin $2-20 \mu \mathrm{g} / \mathrm{kg} / \mathrm{menit}$ atau dopamin $3-20$ $\mu \mathrm{g} / \mathrm{kg} / \mathrm{menit}^{1,13}$

\section{SIMPULAN}

Edema paru kardiogenik (edema volume overload) terjadi karena peningkatan tekanan hidrostatik kapiler paru yang menyebabkan filtrasi cairan trasvaskular. Pada anamnesis ditemukan adanya sesak napas tiba-tiba yang dihubungkan dengan nyeri dada dan adanya riwayat sakit jantung. Edema paru karidogenik merupakan salah satu kegawatan medis yang memerlukan penanganan medis secepat mungkin setelah ditegakkan diagnosis. Penatalaksanaan meliputi pemberian oksigen yang adekuat, restriksi cairan, mempertahankan fungsi kardiovaskular dengan obat-obatan inotropik, serta obat-obatan yang menurunkan preload (nitrat, morfin dan diuretik) dan afterload (ACE inhibitor).

\section{DAFTAR PUSTAKA}

1. Mattu A, Martinez JP, Kelly BS. Modern management of cardiogenic pulmonary edema. Emerg Med Clin N Am. 2005;23:1105-25.

2. Harun S, Sally N. Edema paru akut. In: Sudoyo AW, Setiyohadi B, Alwi I, Simadibrata M, Setiati S, editors. Buku Ajar Ilmu Penyakit Dalam (Edisi ke-5). Jakarta: Pusat Penerbitan Departemen Ilmu Penyakit Dalam Fakultas Kedokteran Universitas Indonesia. 2009; p. 1651-3.

3. Ware LB, Matthay MA. Acute pulmonary edema. N Engl J Med. 2005;353:278896.

4. Nendrastuti H, Mohamad S. Edema paru akut, kardiogenik dan non kardiogenik. Majalah Kedokteran Respirasi. 2010;1(3):10.

5. Majoli F, Monti L, Zanierato $M$, Campana C, Mediani S, Tavazzi L, et al. Respiratory fatigue in patients with acute cardiogenic pulmonary edema. Eur Heart J. 2004;6: F74-80.

6. Prendergast TJ, Ruoss SJ. Pulmonary disease. In: Mc Phee SJ, Lingappa VR, Ganong WF editors. Pathophysiology of Disease, an Introduction to Clinical Medicine (Fourth Edition). New York: Mc-Graw-Hill; 2003. p. 247-51.

7. Murray JF. Pulmonary edema: pathophysiology and diagnosis. Int $\mathbf{J}$ Tuberc Lung Dis. 2011;15(2):155-160.

8. Huldani H. Edema paru akut. Refarat. Universitas Lambung Mangkurat Fakultas Kedokteran, Banjarmasin. 2014. Available from: eprints.unlam.ac.id/207/

9. Salman A, Milbrandt EB, Pinsky MR. The role of noninvasive ventilation in acute 
cardiogenic pulmonary edema. Critical Care. 2010;14(303):1-3.

10. Soemantri. Cardiogenic pulmonary edema. Naskah Lengkap PKB XXVI Ilmu Penyakit Dalam 2011. FK UNAIRRSUD Dr. Soetomo, 2011. p.113-9.

11. Bestern AD. Noninvasive ventilation for cardiogenic pulmonary edema: froth and bubbles? Am J Respir Crit Care Med, 2003.

12. Araújo MCM, Coelho JR. Acute pulmonary edema. [cited: 2003 Nov 6] Available from: http:www.medstudents.com.br/terin/teri n7.htm.

13. Nieminen MS, Bohm M, Cowie MR, Drexler H, Filippatos GS, Jondeau G, et al. Executive summary of the guidelines on the diagnosis and treatment of acute heart failure. Eur Heart J. 2005;26:384-416.

14. Harun S. Edema paru akut. In: Sudoyo AW, Markum HMS, Setiati S, Alwi I, Gani RA, Sumaryono, editors. Naskah lengkap Pertemuan Ilmiah Tahunan Ilmu Penyakit Dalam 1998. Jakarta: Bagian IPD FKUI; 1998. p. 97-101.

15. Rana R, Vlahakis NE, Daniels CE, Jaffe AS, Klee GG, Hubmayr RD, et al. Btype natriuretic peptide in the assessment of acute lung injury and cardiogenic pulmonary edema. [Abstract]. Crit Care Med. 2006;34(7):1941-6.

16. Rodeheffer RJ. Measuring plasma B-type natriuretic peptide in heart failure. J Am Coll Cardiol. 2004;4:740-8.

17. Masip J, Roque $M$, Sanchez B, Fernandez R, Subirana M, Exposito JA. Noninvasive ventilation in cardiogenic pulmonary edema: systematic review and meta-analysis. JAMA. 2005;294:3124-32.

18. Gray A, Goodacre S, Newby DE, Masson M, Sampson F, Nicholl J. Noninvasive Ventilation in Acute Cardiogenic Pulmonary Edema. $\mathrm{N}$ Engl J Med. 2008;359(2):142-51.

19. Agarwal R, Aggarwal AN, Gupta D. Is noninvasive pressure support ventilation as effective and safe as continuous positive airway pressure in cardiogenic pulmonary oedema? Singapore Med J. 2009;50(6):595-603.

20. Winck JC, Azevedo LF, Costa-Pereira A, Antonelli M, Wyatt JC. Efficacy and safety of non-invasive ventilation in the treatment of acute cardiogenic pulmonary edema-a systematic review and meta-analysis. Critical Care. 2006;10(2):1-18 